\title{
Identification of a sheath-associated protein involved in phosphate transport in Sphaerotilus natans
}

\author{
Bryan Kaphammer* and Charles F. Kulpa Jr \\ Department of Biological Sciences, University of Notre Dame, Notre Dame, Indiana 46556, USA
}

Received 7 March 1990/Accepted 23 July 1990

Summary. Sphaerotilus natans was shown to have a fourfold lower $K_{m}^{\prime}$ of phosphate transport when grown in medium containing $0.1 \mathrm{mM}$ phosphate, compared to cells grown in $10.0 \mathrm{~mm}$ phosphate. Analysis of sheath proteins from cells grown at these two phosphate levels revealed a protein of $53 \mathrm{kDa}$ present in the sheath of cells grown at a phosphate concentration of $0.1 \mathrm{~mm}$. This sheath-associated, phosphate-regulated protein, designated SapP, was gel purified and used to raise a polyclonal antibody. Enzyme-linked immunosorbent assay was used to localize this protein to the surface of the sheathed cells. Phosphate uptake assays done in the presence of the antibody also showed a rise in the $K_{m}^{\prime}$ of phosphate transport in cells grown in $0.1 \mathrm{~mm}$ phosphate, indicating that this protein is involved in highaffinity phosphate transport.

\section{Introduction}

Sphaerotilus natans is a Gram-negative sheathed bacterium, characterized by the presence of a contiguous close-fitting sheath enclosing chains of rod-shape cells. The chemical composition of the sheath has been shown to be protein, carbohydrate, and lipid, and functions in the attachment of $S$. natans filaments to solid objects. Presumably this gives the organism a selective advantage in environments that contain low nutrient levels (Romano and Peloquin 1963).

The growth and physiology of $S$. natans have both economic and environmental importance in the area of waste-water treatment (Chiesa and Irvine 1985). The predominance of $S$. natans in an activated sludge environment results in poor settling characteristics of the sludge. Among the environmental conditions that can cause proliferation of this organism is low influent

\footnotetext{
* Present address: 1301 Catherine Medical Science II 5605, University of Michigan, Ann Arbor, MI 48109, USA
}

Offprint requests to: $\mathrm{C}$. F. Kulpa $\mathrm{Jr}$ phosphorus (Hattingh 1963). However, there is little information on the physiology of S. natans as it relates to low phosphate environments. Gaudy and Wolfe (1961) demonstrated that $S$. natans grows in a narrow range of phosphate concentrations, with $10 \mathrm{~mm}$ phosphate being optimal. The concentration of phosphate affects the amount of biomass, but not sheath formation.

Phosphate starvation has been shown to result in the synthesis of several proteins in Escherichia coli (Tomassen and Lugtenberg 1980). One of these proteins (PhoE) is an outer-membrane, anion-specific pore that facilitates the diffusion of organic and inorganic phosphate through the outer membrane (Korteland et al. 1982). This study was undertaken to examine if phosphate starvation results in synthesis of new sheath proteins, and if so, whether these proteins are involved in phosphate transport in $S$. natans.

\section{Materials and methods}

Bacterial strains, media, and growth conditions. The $S$. natans strain used was ATCC 13338. Cultures were routinely maintained on solid medium composed of $5 \mathrm{~g} / 1$ casitone, $1 \mathrm{~g} / 1$ glucose, $1 \mathrm{~g} / 1$ yeast extract, and $15 \mathrm{~g} / 1$ agar (CGY). Phosphate limited and nonlimited cultures were grown in a defined medium containing $5.2 \mathrm{~g} / 1$ HEPES (N-2-hydroxyethylpiperazine- $\mathrm{N}^{\prime}$-2-ethanesulfonic acid), $1 \mathrm{~g} / 1$ glucose, $0.1 \mathrm{~g} / 1 \mathrm{MgSO}_{4}-7 \mathrm{H}_{2} \mathrm{O}, 0.36 \mathrm{~g} / 1 \mathrm{NH}_{4} \mathrm{Cl}_{2}$, and $0.01 \mathrm{~g} / 1 \mathrm{CaCl}_{2}$. The $\mathrm{pH}$ was adjusted to 7.2 and the medium was autoclaved. After cooling, $1 \mathrm{ml}$ sterile $\mathrm{FeCl}_{3}$-EDTA solution $(2 \mathrm{~g} / 1$ $\mathrm{FeCl}_{3}, 3 \mathrm{~g} / \mathrm{l}$ EDTA) was added, followed by the addition of filtersterilized vitamin $B_{12}$ to a final concentration of $5 \mu \mathrm{g} / \mathrm{l}$. This medium was designated HGM. Potassium phosphate buffer was added to $0.1 \mathrm{~mm}$ for phosphate-limited growth and $10.0 \mathrm{~mm}$ for non-limited growth. Erlenmeyer flasks $(125 \mathrm{ml})$ containing $50 \mathrm{ml}$ HGM at a phosphate concentration of $10 \mathrm{~mm}$ or $0.1 \mathrm{~mm}$ were inoculated with $1 \mathrm{ml}$ of a turbid suspension of $S$. natans and incubated at $30^{\circ} \mathrm{C}$ on an orbital shaker at $150 \mathrm{rpm}$ for $24 \mathrm{~h}$. These cultures were used as inoculum for fresh HGM $(100 \mathrm{ml}$ in a 250 $\mathrm{ml}$ erlenmeyer flask) at phosphate concentrations of $10 \mathrm{~mm}$ or $0.1 \mathrm{mM}$ and incubated at $30^{\circ} \mathrm{C}$ on an orbital shaker at $150 \mathrm{rpm}$ to mid-log phase. These cultures were used in all experiments that required phosphate-limited and non-limited cells.

Bacterial growth rates. Cultures of $S$. natans were grown under phosphate-limiting and non-limiting conditions and $1-\mathrm{ml}$ samples 
were collected at various times. The samples were washed and resuspended in sterile distilled water. Each sample was assayed for total protein by the Lowry method (Lowry et al. 1951). Bovine serum albumin (BSA) was used as a standard.

Sheath isolation and protein analysis. Sheath material was isolated by modifying the method of Romano and Peloquin (1963). Modifications included incubating the cultures at $30^{\circ} \mathrm{C}$ in the lysozymeEDTA buffer instead of at $37^{\circ} \mathrm{C}$, and then pelleting the sheath by ultracentrifugation at $40000 \mathrm{~g}$ for $30 \mathrm{~min}$. The sheath pellet was washed three times with $30 \mathrm{~mm}$ TRIS- $\mathrm{HCl}$, pH 7.0 .

Proteins were extracted from the sheath by resuspending purified sheath from a 1.5-l culture in $10 \mathrm{ml}$ extraction buffer, which consisted of $6.3 \mathrm{mM}$ TRIS-HCl, pH $6.8,2 \%$ sodium dodecyl sulfate (SDS), and 5\% 2-mercaptoethanol. The sheath proteins were solubilized by repeated passage through an 18-gauge hypodermic needle followed by passage through a 23 -gauge needle. This sheath suspension was subjected to ultracentrifugation at $40000 \mathrm{~g}$ for $30 \mathrm{~min}$. The supernatant, which contained the extracted sheath proteins, was saved and $10 \mathrm{ml}$ extraction buffer was added to the pellet. The pellet was resuspended by passage through an 18 gauge hypodermic needle followed by passage through a 23-gauge needle, and then subjected to ultracentrifugation at $40000 \mathrm{~g}$ for $30 \mathrm{~min}$. The supernatant was saved and $10 \mathrm{ml}$ of extraction buffer was used to resuspend the pellet by passage through the same needles followed by ultracentrifugation at $40000 \mathrm{~g}$ for $30 \mathrm{~min}$. The supernatant from this extraction was combined with the other supernatants and the proteins were precipitated by adding $150 \mathrm{ml}$ ice-cold acetone. This acetone mixture was aliquoted to eight 30 $\mathrm{ml}$ Corex tubes, which were then incubated for $30 \mathrm{~min}$ at $-70^{\circ} \mathrm{C}$. The precipitated proteins were pelleted by centrifugation at $12000 \mathrm{~g}$ for $15 \mathrm{~min}$. Supernatants were discarded and $2 \mathrm{ml}$ buffer containing $2 \%$ SDS in $6.2 \mathrm{mM}$ TRIS- $\mathrm{HCl}, \mathrm{pH} 6.8$, was added to each pellet and the tubes were boiled for $10 \mathrm{~min}$ to solubilize the proteins.

Sheath proteins from cells grown in HGM with $0.1 \mathrm{mM}$ and $10 \mathrm{mM}$ phosphate were analyzed by SDS-polyacrylamide gel electrophoresis (PAGE) using the method of Laemmli (1970), with $10 \%$ polyacrylamide gel.

Gel purification of SapP. Preparation SDS-PAGE was performed on sheath proteins of $S$. natans grown in HGM with $0.1 \mathrm{mM}$ phosphate. The proteins in the gel were visualized by the $\mathrm{KCl}$ method of Hagar and Burgess (1980). The protein band corresponding to SapP was cut out of the gel and electroeluted. The eluted protein was precipitated by the acetone precipitation method described by Hagar and Burgess (1980).

Immunization procedure. Two-hundred micrograms of gel-purified SapP in $250 \mu 1$ normal saline was emulsified with $250 \mu \mathrm{l}$ Freund's Complete Adjuvant. The emulsion was injected into a young adult female New Zealand White rabbit both intramuscularly $(400 \mu 1)$ and intraperitoneally $(100 \mu 1)$. On days $14,21,28$, and 35 the rabbit was injected intramuscularly with $100 \mu \mathrm{g}$ gel-purified SapP in $100 \mu$ l normal saline, emulsified with $100 \mu$ Incomplete Freund's Adjuvant. On day 42, $100 \mu \mathrm{g}$ gel-purified SapP was injected intramuscularly and intraperitoneally. On day 49 , the serum was collected.

Immunoblotting procedure. Immunoblotting of SDS-PAGE gels was done by the method of Towbin et al. (1979). The nitrocellulose, which contained the sheath proteins, was incubated for $1 \mathrm{~h}$ at $37^{\circ} \mathrm{C}$ in $20 \mathrm{mM}$ TRIS- $\mathrm{HCl}$, pH $7.5,500 \mathrm{~mm} \mathrm{NaCl}$ (TBS) to which gelatin had been added to $2 \%$. The TBS- $2 \%$ gelatin was discarded and anti-SapP antiserum was added at a concentration of $1 \%$ in TBS- $2 \%$ gelatin. The blot was allowed to incubate for $90 \mathrm{~min}$ at room temperature followed by five washes of $6 \mathrm{~min}$ each in TBS containing $0.05 \%$ Tween 20 . After the last wash was discarded goat-anti-rabbit alkaline phosphatase at a concentration of $0.5 \%$ in TBS- $2 \%$ gelatin was added and the blot was allowed to incubate at room temperature for $90 \mathrm{~min}$ followed by five washes of $6 \mathrm{~min}$ each in TBS containing $0.05 \%$ Tween 20 .
Goat-anti-rabbit alkaline phosphatase bound to the blot was detected by the nitro blue tetrazolium, 5-bromo-4-chloro-indolylphosphate method of Blake et al. (1984).

Enzyme-linked immunosorbant assay (ELISA). Whole cell ELISA was performed by placing $50 \mu \mathrm{l}$ of an $S$. natans cell suspension, which had been grown in HGM with $0.1 \mathrm{~mm}$ or $10 \mathrm{~mm}$ phosphate, washed twice with sterile distilled water, and resuspended in buffer consisting of $0.1 \mathrm{M}$ ammonium acetate, $0.1 \mathrm{M}$ ammonium carbonate, $\mathrm{pH} 8.2$, to a concentration of $30 \mu \mathrm{g} / \mathrm{ml}$ total cellular protein, into each well of a microtiter plate. Plates were incubated at $37^{\circ} \mathrm{C}$ until dry. ELISA buffer $(50 \mu \mathrm{l})$, consisting of $10 \mathrm{~mm}$ $\mathrm{Na}_{2} \mathrm{HPO}_{4}, \mathrm{pH} 7.2,1 \% \mathrm{BSA}, 0.5 \%$ Tween 20 , and $0.02 \%$ sodium azide, was added and the plates were incubated for $30 \mathrm{~min}$ at room temperature. The ELISA buffer was removed and $50 \mu 1$ antiSapP antiserum or pre-immune serum diluted in ELISA buffer to $1: 1,1: 10,1: 100,1: 200,1: 300,1: 600$, or $1: 1000$ was added. Plates were incubated for $1 \mathrm{~h}$ at room temperature, washed five times with ELISA buffer followed by the addition of $50 \mu$ of a $1: 1000$ dilution of goat-anti-rabbit alkaline phosphatase in ELISA buffer to each well. Plates were incubated for $1 \mathrm{~h}$ at room temperature, washed five times with ELISA buffer, and then $50 \mu \mathrm{lof}$ a $1 \mathrm{mg} / \mathrm{ml}$ solution of $p$-nitrophenyl-phoshate in substrate buffer $(9.7 \%$ diethanolamine, $0.1 \mathrm{~g} / 1 \mathrm{MgCl}_{2} \cdot 6 \mathrm{H}_{2} \mathrm{O}, 0.2 \mathrm{~g} / 1$ sodium azide, $\mathrm{pH} 9.8$ ) was added to each well. After incubation for $30 \mathrm{~min}$ the reaction was stopped by the addition of $25 \mu \mathrm{l}$ of $1 \mathrm{M} \mathrm{NaOH}$. The optical density of each well was read at a wavelength of $405 \mathrm{~nm}$.

Phosphate uptake kinetics. Cultures $(100 \mathrm{ml})$ of $S$. natans were grown under phosphate-limited and non-limited conditions to mid-log phase, harvested, washed twice with uptake buffer $(5.2 \mathrm{~g} /$ 1 HEPES, pH 7.2, $1 \mathrm{~g} / 1$ glucose, $0.1 \mathrm{~g} / 1 \mathrm{MgSO}_{4} \cdot 7 \mathrm{H}_{2} \mathrm{O}, 0.36 \mathrm{~g} / 1$ $\mathrm{NH}_{4} \mathrm{Cl}_{2}, 0.01 \mathrm{~g} / 1 \mathrm{CaCl}_{2}$ ) and finally resuspended in $40 \mathrm{ml}$ of uptake buffer. Uptake was initiated by adding $200 \mu \mathrm{l}$ radiolabeled ${ }^{32} \mathrm{P}(1.0 \mathrm{Ci} / \mathrm{mmole})$ to $1.8 \mathrm{ml}$ cells. Samples $(100 \mu \mathrm{l})$ were removed every $10 \mathrm{~s}$ and placed on $0.45-\mu \mathrm{m}$ Gelman Merricel (Fisher Scientific, Co., Itasca, IL) filters, which had been soaked for $24 \mathrm{~h}$ in $0.01 \mathrm{M}$ phosphate buffer, pH 7.0. Each filter was immediately washed with $6 \mathrm{ml}$ uptake buffer and air dried. Radioactivity was detected by placing filters in $10 \mathrm{ml}$ scintillation fluid $(53 \mathrm{ml} 2,5-$ diphenyloxazole(PPO)-phenyloxazoylphenyloxazolylphenyl (POPOP) concentrate/ 1 toluene, obtained from National Diagnostics (Highland Park, N. J., USA) and counted in a Beckman (Palo Alto, Calif.) LS 7000 scintillation counter. Background was determined by performing the assays without cells.

Phosphate uptake assays were also performed in the presence of anti-SapP antibody or pre-immune serum at a dilution of $1: 10$ in uptake buffer. Cells were incubated with the antibody solutions for $30 \mathrm{~min}$ and then assayed for phosphate uptake as before.

\section{Results}

\section{Phosphate-limited and non-limited growth}

A defined medium was designed (HGM), which contained all the necessary nutrients with the exception of phosphate. $S$. natans was grown in HGM with either $0.1 \mathrm{mM}$ or $10 \mathrm{mM}$ phosphate as described in Materials and methods. Growth curves were constructed and generation times were calculated to be $4.4 \mathrm{~h}$ for cells grown in $0.1 \mathrm{~mm}$ phosphate and $3.8 \mathrm{~h}$ for cells grown in $10 \mathrm{~mm}$ phosphate. The final cell mass, after $72 \mathrm{~h}$ incubation was $75 \mu \mathrm{g} / \mathrm{ml}$ for the $0.1 \mathrm{mM}$ phosphate culture and $126 \mu \mathrm{g} / \mathrm{ml}$ for the $10 \mathrm{~mm}$ phosphate culture. These data suggest that $S$. natans grown in HGM with $0.1 \mathrm{mM}$ phosphate had its growth limited due to the amount of phosphate in the medium. 
Table 1. Phosphate uptake kinetics of Sphaerotilus natans

\begin{tabular}{rlrl}
\hline $\begin{array}{l}\text { Phosphate } \\
\text { concentration } \\
(\mathrm{mM})^{\mathrm{a}}\end{array}$ & Antibody & $K_{m}^{\prime}(\mu \mathrm{M})$ & \multicolumn{1}{l}{$\begin{array}{l}V_{\max } \\
\text { (nmol/s/mg } \\
\text { dry weight) }\end{array}$} \\
\hline 10.0 & None & $16.90 \pm 0.2$ & $0.14 \pm 0.01$ \\
0.1 & None & $4.46 \pm 0.7$ & $0.19 \pm 0.02$ \\
10.0 & AS & $16.60 \pm 3.9$ & $0.10 \pm 0.02$ \\
0.1 & AS & $22.60 \pm 3.4$ & $0.28 \pm 0.06$ \\
10.0 & PI & $14.60 \pm 2.8$ & $0.08 \pm 0.04$ \\
0.1 & PI & $3.56 \pm 1.1$ & $0.12 \pm 0.03$ \\
\hline
\end{tabular}

a Phosphate concentration ( $\mathrm{mM}$ ) in the growth media

b Cells were incubated with anti-sheath-associated, phosphateregulated protein (AS) or pre-immune (PI) antisera before phosphate uptake assays as described in Materials and methods

\section{Phosphate uptake kinetics}

Phosphate uptake experiments were performed to examine differences in phosphate transport kinetics in $S$. natans grown under phosphate-limiting and non-limiting conditions. Experiments were run at six phosphate concentrations ranging from $0.7 \mu \mathrm{M}$ to $4.0 \mu \mathrm{M}$. Data were corrected for background and rates of phosphate transport were calculated. There was no significant difference in the $V_{\max }$ between the two populations (Table 1). However, there was a fourfold $K_{m}^{\prime}$ of transport effect (Table 1) indicating that there is a difference in phosphate permeability between $S$. natans grown at $10 \mathrm{mM}$ or $0.1 \mathrm{mM}$ phosphate (Nikaido 1979).

\section{Identification of SapP}

Analysis of sheath proteins by SDS-PAGE was complicated by the fact that these proteins are associated with the carbohydrates of the sheath. An extraction procedure was developed allowing easy analysis of the sheath proteins. The results of SDS-PAGE of these sheath proteins are shown in Fig. 1, lanes B and C. This analysis shows that there is a $53 \mathrm{kD}$ phosphate-regulated, sheath-associated protein in the sheath of cells grown in $0.1 \mathrm{~mm}$ phosphate, but not in the sheath of cells grown in $10 \mathrm{~mm}$ phosphate. This $53 \mathrm{kDa}$ protein was designated SapP.

\section{Localization of SapP}

The protein band corresponding to SapP was visualized, cut out of the preparative polyacrylamide gel, eluted and a polyclonal antiserum was raised to this denaturated protein. The anti-SapP serum was analyzed for its specificity to SapP by using it as the primary antibody in immunoblots of sheath proteins from $S$. natans grown under phosphate-limited and non-limited conditions (Fig. 1, lanes D and E). These results demonstrate that the anti-SapP antiserum is specific for SapP, and the SapP is only found in sheath prepara-

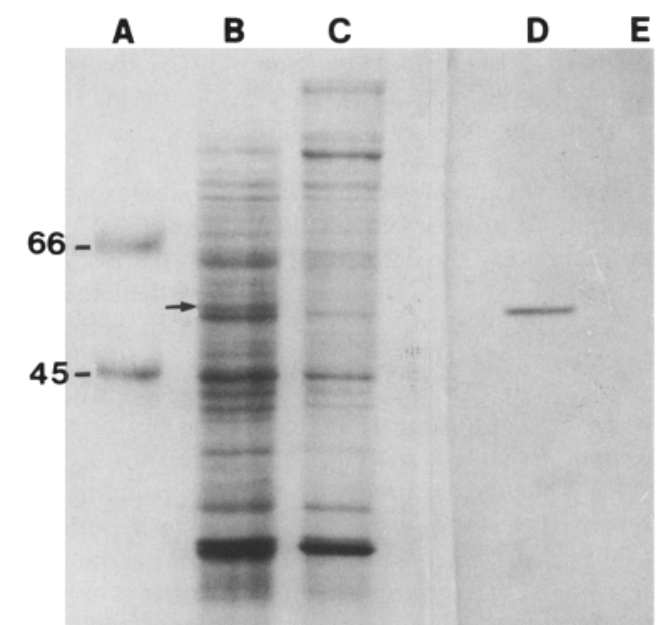

18.4

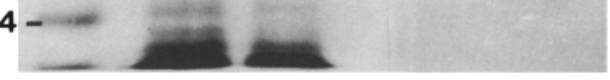

Fig.1. Sodium dodecyl sulfate-polyacrylamide gel electrophoresis (SDS-PAGE) and immunoblot of Sphaerotilus natans sheath proteins using anti-sheath-associated, phosphate regulated protein (SapP) antiserum. Lanes $A, B$, and $C$ are SDS-PAGE stained with Coomasie blue: $A$, molecular weight standards in kilodaltons; $B$, sheath proteins from cells grown in HGM (see Materials and methods) with $0.1 \mathrm{~mm}$ phosphate; $C$, sheath proteins from cells grown in HGM with $10 \mathrm{~mm}$ phosphate; Lane $D$, immunoblot of lane B; Lane $E$ : immunoblot of lane $\mathrm{C}$

tions of cells grown under phosphate-limited conditions.

Since SapP is a sheath-associated protein and the sheath is the outermost layer, the question was asked whether SapP could be detected on the surface of whole cells. An ELISA assay was done using $S$. natans grown under phosphate-limited and non-limited conditions. The results in Fig. 2 show that SapP can be detected on the surface of cells grown under phosphatelimited conditions. There was some reaction with cells grown under non-limited conditions which could indicate a basal level of SapP expression.

\section{Phosphate transport in the presence of anti-SapP}

SapP has been demonstrated to be a phosphate-regulated, sheath-associated protein. However, the question remains whether SapP is directly involved in phosphate transport. If so, it may be possible to hinder SapP by blocking its active site with antibody. Phosphate uptake experiments were performed in the presence of antiSapP antiserum, and parallel experiments were also done using the same concentration of pre-immune serum as a control.

$S$. natans grown under phosphate-limited conditions and assayed in the presence of anti-SapP showed a fivefold higher $K_{m}^{\prime}$ than the same cells assayed in the presence of pre-immune serum (Table 1). Cells grown 


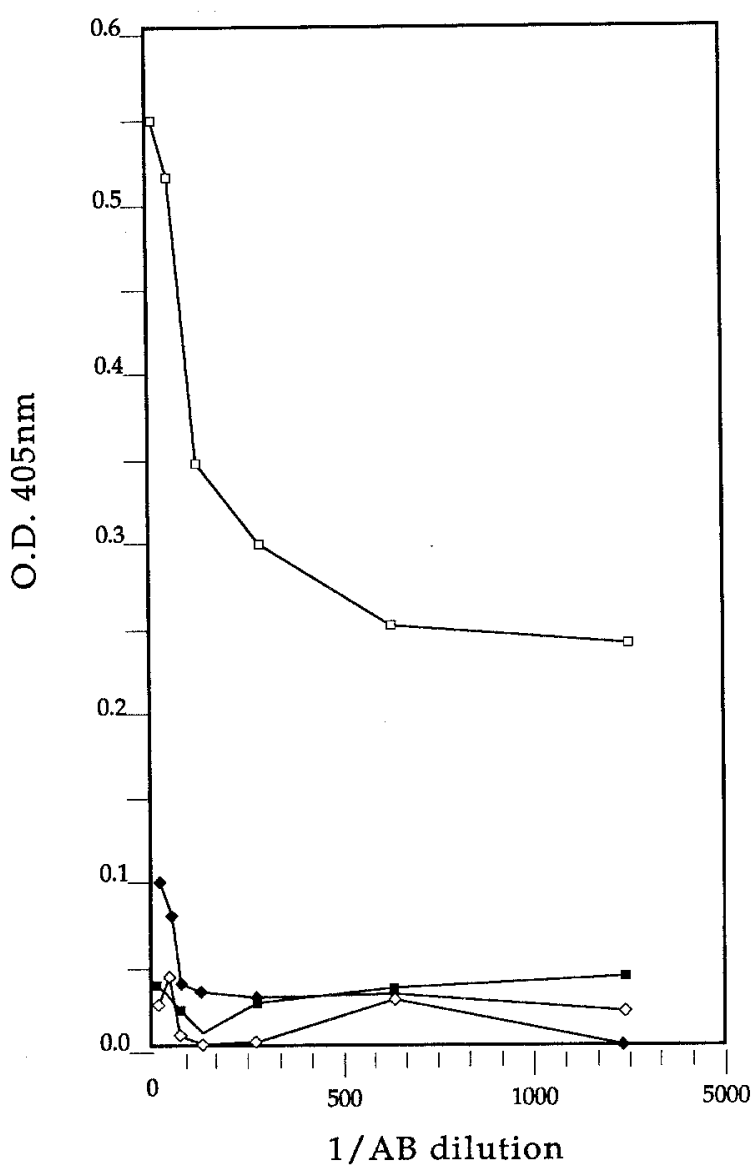

Fig. 2. Enzyme-linked immunosorbent assay (ELISA) of $S$. natans whole cells: $\square$, cells grown in HGM with $0.1 \mathrm{mM}$ phosphate and assayed with anti-SapP; $\diamond$, cells grown in HGM with $10 \mathrm{mM}$ phosphate and assayed with anti-SapP; $\boldsymbol{\square}$, cells grown in HGM with $0.1 \mathrm{~mm}$ phosphate and assayed with pre-immune serum; $\diamond$, cells grown in HGM with $10 \mathrm{mM}$ phosphate and assayed with preimmune serum

under non-limiting conditions showed no difference in the $K_{m}^{\prime}$ when assayed in the presence of either antiSapP or pre-immune serum (Table 1). The $V_{\max }$ of both populations was only slightly affected by the presence of the anti-SapP antibody.

The fivefold $K_{m}^{\prime}$ effect seen in the phosphate-limited cells indicates that anti-SapP is specifically interfering with phosphate transport. Since the anti-SapP antiserum has been shown to be specific for the SapP protein it can be concluded that SapP is involved in phosphate transport.

\section{Discussion}

Phosphate transport was studied as a model of the role of the sheath in the physiology of $S$. natans. The available data indicate that $S$. natans could become predominant in a waste-water environment that was limited in phosphate (Hattingh 1963). These data suggested that $S$. natans has a higher affinity for phosphate relative to the other organisms in the environment.
The results of phosphate transport assays suggest that there is an inducible phosphate transport system in $S$. natans. The fourfold $K_{m}^{\prime}$ effect between cells grown under phosphate-limited and non-limited conditions suggests that there is a change in the permeability of the outer envelope of the cell (the outer envelope being the outer membrane and sheath). This type of $K_{m}^{\prime}$ effect has been demonstrated in several $E$. coli outer membrane proteins mutants (Korteland et al. 1982; Nikaido 1979).

This is the first report of a sheath protein that is involved in phosphate transport and raises questions concerning the mechanism of action of SapP. The sheath proteins could be outer membrane proteins that are associated with the carbohydrates of the sheath. The association of Gram-negative outer-membrane proteins with the carbohydrate structure of the cell wall has been documented (Tokunaga et al. 1979). The ELISA results demonstrate that SapP is exposed on the surface of the sheath, and the phosphate transport experiments done in the presence of anti-SapP antibody demonstrate that SapP has a role in high-affinity phosphate transport in $S$. natans. The nature of this role can only be speculated. SapP could aid in phosphate uptake by directing phosphate to specific membrane proteins involved in transport. This could be accomplished in several ways. If SapP were a phosphate-binding protein it could sequester phosphate and make it available to the membrane transport systems. SapP could also interact with outer-membrane pore proteins, thereby effectively increasing the surface area of the membrane and thus the velocity of diffusion.

The fact that anti-SapP antibody interferes with phosphate transport suggests that it is a phosphatebinding protein. Attempts to block transport of cefsulodin (a beta-lactam antibiotic) through the E. coli anion specific pore protein, $\mathrm{PhoE}$, using both monoclonal and polyclonal antisera were not successful (van der Ley et al. 1985), suggesting that important recognition sites are not located on the outer surface of this pore protein. If SapP were a pore protein, it could be speculated that its important recognition sites would also be unavailable to antibody and thus anti-SapP would not have affected phosphate transport.

The sheath structure itself would be a good location for binding proteins, allowing $S$. natans to scavenge the available nutrients from the environment, making them unavailable for the other members of the community. This could be an explanation for $S$. natans becoming predominant in low phosphate environments.

Acknowledgement. This work was supported by grant CEE 811253-02 from the National Science Foundation.

\section{References}

Blake MS, Johnston KH, Russell-Jones GJ, Gotschlich EC (1984) $A$ rapid and sensitive method for detection of alkaline phosphatase-conjugated anti-antibody on Western blots. Anal Biochem 136:175-179 
Chiesa SC, Irvine RL (1985) Growth and control of filamentous microbes in activated sludge: an integrated hypothesis. Water Res 19:471-479

Gaudy E, Wolfe RS (1961) Factors affecting filamentous growth of Sphaerotilus natans. Appl Microbiol 9:580-584

Hagar DA, Burgess RR (1980) Elution of proteins from sodium dodecyl sulfate-polyacrylamide gels, removal of sodium dodecyl sulfate, and renaturation of enzymatic activity: results with sigma subunit of Escherichia coli RNA polymerase, wheat germ DNA topoisomerase, and other enzymes. Anal Biochem 109:76-86

Hattingh WHJ (1963) The nitrogen and phosporus requirements of the microorganisms. Water Waste Treat 9:380-385

Korteland J, Tommassen J, Lugtenberg B (1982) PhoE protein pore of the outer membrane of Escherichia coli $\mathrm{K}-12$ is a particularly efficient channel for organic and inorganic phosphate. Biochim Biophys Acta 690:282-284

Ley $\mathrm{P}$ van der, Amesz H. Tommassen J, Lugtenberg B (1985) Monoclonal antibodies directed against the cell-surface exposed part of PhoE pore protein of the Escherichia coli K-12 outer membrane. Eur J Biochem 147:401-407
Laemmli UK (1970) Cleavage of structural proteins during the assembly of the head of bacteriophage T4. Nature 227:680-685

Lowry OH, Rosebrough NJ, Farr AL, Randall RJ (1951) Protein measurement with the Folin phenol reagent. J Biol Chem $193: 265-275$

Nikaido $\mathbf{H}(1979)$ Nonspecific transport through the outer membrane. In: Inouye M (ed) Bacterial outer membranes: biogenesis, and function. Wiley, New York, pp 380-385

Romano AH, Peloquin JP (1963) Composition of the sheath of Sphaerotilus natans. J Bacteriol 86:252-258

Tokunaga M, Tokunaga H, Okajimu Y, Nakae T (1979) Characterization of porins from the outer membrane of Salmonella typhimurium. Eur J Biochem 95:441-448

Tomassen J, Lugtenberg B (1980) Outer membrane protein E of Escherichia coli $\mathrm{K}-12$ is co-regulated with alkaline phosphatase. J Bacteriol 143:151-157

Towbin H, Stachlin T, Gordon J (1979) Electrophoretic transfer of proteins from polyacrylamide gels to nitrocellulose sheets: procedure and some applications. Proc Natl Acad Sci USA $76: 4350-4354$ 